\title{
Evaluasi Program Pembelajaran Pemeliharaan Kelistrikan Sepeda Motor Menggunakan Model CIPP
}

\author{
Endrizal $^{1 *}$, Wakhinuddin², Waskito ${ }^{3}$ iD \\ 1,2,3 Program Studi Pendidikan Teknik Otomotif, Universitas Negeri Padang, Sumatera Barat, Indonesia \\ *Corresponding author: endrizalned3@gmail.com
}

\begin{abstract}
Abstrak
Penelitian bertujuan untuk mengevaluasi program pembelajaran pemeliharaan kelistrikan sepeda motor di SMK. Jenis penelitian yang digunakan adalah penelitian evaluasi dengan model CIPP (Context, Input, Process, Product). Metode penelitian yang digunakan adalah metode kombinasi (Mixed Method Research) dengan jumlah responden penelitian 36 orang, informan data kualitatif 8 orang sedangkan data kuantitatif menggunakan total sampling sebanyak 28 siswa. Teknik pengumpulan data melalui observasi, angket, dokumentasi, dan wawancara. Teknik analisis yang digunakan yautu teknik analisis data kualitatif dan teknik analisis data kuantitatif menggunakan analisis persentase. Hasil penelitian menunjukkan komponen konteks tergolong kategori baik dengan perolehan persentase $(82,80 \%)$. Komponen masukan tergolong kategori baik dengan perolehan persentase $(81,70 \%)$. Komponen proses tergolong kategori baik dengan perolehan persentase $(82,62 \%)$, dan komponen hasil tergolong kategori cukup dengan perolehan persentase $(76,28 \%)$. Dari data tersebut dapat disimpulkan bahwa dalam pelaksanaan program pembelajaran pemeliharaan kelistrikan sepeda motor sudah berada pada kategori baik, tetapi beberapa aspek masih terdapat kekurangan, maka dari itu untuk mendapatkan hasil yang optimal harus lakukan perbaikan terhadap aspek tersebut.
\end{abstract}

Kata kunci: Program Pembelajaran, Kelistrikan, Model CIPI

\section{Abstract}

The research aims to evaluate the learning program for motorbike electrical maintenance at SMK. This type of research is evaluation research with the CIPP (Context, Input, Process, Product) model. The research method used is a combination method (Mixed Method Research) with the number of research respondents 36 people, qualitative data informants 8 people while quantitative data using a total sampling of 28 students. Data collection techniques through observation, questionnaires, documentation, and interviews. The analysis technique used is qualitative data analysis techniques and quantitative data analysis techniques using percentage analysis. The results showed that the context component was categorized as good with a percentage gain (82.80\%). The input component belongs to the good category with a percentage gain (81.70\%). The process component is classified as good with a percentage gain (82.62\%), and the yield component is classified as a sufficient category with a percentage gain (76.28\%). From these data it can be concluded that in the implementation of the learning program for motorbike electrical maintenance, it is in the good category, but some aspects still have shortcomings, therefore to get optimal results, improvements must be made to these aspects.

Keywords: Learning Program, Electricity, CIPI Model

History:
Received : 1 Januari 2021
Revised : 15 Januari 2021
Accepted : 1 Maret 2021
Published : 25 Maret 2021

Publisher: Undiksha Press

Licensed: This work is licensed under

a Creative Commons Attribution 4.0 License

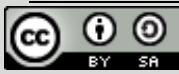

\section{Pendahuluan}

Kurikulum adalah alat untuk mencapai tujuan pendidikan yang pada dasarnya memiliki komponen pokok dan komponen penunjang yang saling berkaitan dan berinteraksi satu sama lainnya dalam rangka mencapai tujuannya (M. Z. Arifin et al., 2018). Kurikulum di 
Indonesia selalu mengalami perubahan akibat dari kemajuan IPTEK menuntut pendidikan pada jenjang di setiap sekolah khususnya tingkat SMK harus menyesuaikan dan mengantisipasi setiap perubahan yang terjadi (Muhammedi, 2016; Slameto, 2015). Pengembangan kurikulum, selain mempertimbangan landasan filosofis, sosiologis, psikopedagogis, teoritis, dan landasan yuridis (Djuandi, 2013), juga mengacu pada pertimbangan dengan prinsip-prinsip pengembangan kurikulum, yang digunakan sebagai kaidah yang harus ditempuh suatu kurikulum yang akan disusun atau dikembangkan. Dalam kurikulum terdapat proses pengembangan yang secara umum terdiri dari perencanaan, implementasi dan evaluasi (Fajri, 2019). Oleh sebab itu, pada proses pembelajaran setiap dituntut untuk mampu melakukan perencanaan pembelajaran dengan baik, sehingga pelaksanaan proses pembelajaran dapat berjalan maksimal, selain itu penilaian proses pembelajaran mampu diarahkan untuk meningkatkan efisiensi dan efektivitas ketercapaian kompetensi.

Kenyataannya, sebagian besar lulusan sekolah menengah kejuruan belum bisa memenuhi kebutuhan dan tuntutan dari dunia usaha dan dunia industri (Z. Arifin et al., 2012). Hal ini mengindikasikan bahwa kualitas dari lulusan SMK belum sesuai dengan yang diharapkan, baik dari segi sikap, pengetahuan, dan keterampilan. Hal ini dikarenakan masih banyak SMK yang belum bisa mengikuti perkembangan teknologi terbaru, sekolah tradisional yang hanya menoleh kebelakang pasti tidak dapat memberikan pendidikan yang relevan. Di SMK Negeri 1 Bukittinggi Secara umum kemampuan siswa dalam pembelajaran pemeliharaan kelistrikan sepeda motor masih rendah dibandingkan dengan standar industri. Hal ini dapat dilihat pada kemampuan siswa dalam memecahkan permasalahan yang dikemukakan dalam pembelajaran pemeliharaan kelistrikan sepeda motor. Berdasarkan observasi awal yang dilakukan terdapat beberapa permasalahan yang dihadapi antara lain, 1) Perkembangan teknologi dibidang teknik sepeda motor kurang terimbangi dengan peningkatan sumber daya manusia dalam dunia pendidikan. 2) Perkembangan teknologi dibidang teknik sepeda motor khusus bidang kelistrikan yang sudah otomasi kurang terimbangi dengan sarana prasaran pembelajaran. 3) Kurang minat siswa untuk memiliki buku bacaan yang relevan 4)Kurang mampu guru membuat perangkat pembelajaran dengan baik. 5) Jumlah siswa saat praktikum tidak sesuai dengan luas ruangan yang ada dan yang paling mendasar adalah 6) Belum adanya evaluasi program pembelajaran pemeliharaan kelistrikan sepeda motor yang dilakukan di SMK Negeri 1 Bukittinggi. Hal ini dapat dilihat dari hasil dari nilai akhir semester pembelajaran pemeliharaan kelistrikan sepeda motor yang dirangkum selama tiga tahun, rata-rata kompetensi siswa yang dicapai juga masih rendah

Untuk itulah pengembangan kurikulum yang relevan dengan kebutuhan masyarakat saat ini mutlak diperlukan. Kurikulum yang digunakan hendaknya dinamis, fleksibel, yakni dapat dirubah sesuai dengan perubahan masyarakat. Sehubungan dengan hal itu, maka evaluasi program pembelajaran dilakukan dengan dituan untuk melihat sejauh mana hasil belajar telah tercapai dengan optimal sesuai dengan target dan tujuan pembelajaran. salah satu model evaluasi yang digunakan yaitu model CIPP. Model CIPP memberikan gambaran yang jelas serta terstruktur dalam mengevaluasi keberhasilan suatu program. Model CIPP berpijak pada pandangan bahwa tujuan terpenting dari evaluasi program bukanlah membuktikan (to prove), melainkan meningkatkan (to improve) (Sakti, 2018; Wijayanti et al., 2019). Artinya, model CIPP diterapkan dalam rangka mendukung pengembangan organisasi dan membantu pemimpin dan staf organisasi tersebut mendapatkan dan menggunakan masukan secara sistematis supaya lebih mampu memenuhi kebutuhan-kebutuhan penting atau, minimal, bekerja sebaik-baiknya dengan sumber daya yang ada. Pada dasarnya tujuan evaluasi adalah untuk memperoleh data atau informasi akurat dan objektif tentang pelaksanaan suatu program (Munthe, 2015). Informasi tersebut dapat dampak atau hasil yang dicapai, proses, efisiensi atau pemanfaatan pendayagunaan sumber daya. 
Beberapa penelitian sebelumnya menunjukkan bahwa evaluasi program pembelajaran dengan model CIPP dinyatakan cukup efektif (Budi Yoga Bhakti, 2017). Temuan penelitian mengenai evaluasi program pendidikan pemakai dengan model CIPP di perpustakaan Fakultas Teknik UGM menghasilkan evaluasi setiap komponen program pendidikan cukup baik (Wijayanti et al., 2019). Temuan lain menyatakan evaluasi pemanfaatan program information communication technology (ICT) menggunakan model CIPP pada sekolah menengah di Kota Padang memperoleh evaluasi yang jelas menggunakan model CIPP (Hidayati, 2010). Selain itu, model CIPP digunakan untuk mengevaluasi pembelajaran di PAUD inklusif menghasilkan evaluasi setiap komponen cukup baik (Junanto \& Kusna, 2018).

Mengingat masalah ini sangat mendasar, maka peneliti tertarik untuk menganalisis tentang evaluasi program pembelajaran pemeliharaan kelistrikan sepeda motor SMK Negeri 1 Bukittinggi dengan pendekatan model evaluasi CIPP. Sasaran evaluasi adalah komponen pembelajaran pemeliharaan kelistrikan sepeda motor SMK Negeri 1 Bukittinggi antara lain: perencanan program pembelajaran, pelaksanaan program pembelajaran dan hasil pembelajaran.

\section{Metode}

Jenis penelitian yang digunakan pada adalah penelitian evaluasi dengan model CIPP (Context, Input, Process, Product)dan metode penelitian yang digunakan adalah metode kombinasi (Mixed Method). Penelitian ini dilaksanakan di SMK Negeri 1 Bukittinggi dengan Objek penelitian lingkungan (kebutuhan, peluang, aset, dan masalah), guru (kualifikasi dan kompetensi), siswa (minat dan motivasi), sarana dan prasarana, aktivitas guru, aktivitas siswa, hasil belajar, potensi yang dimiliki, kecakapan, bakat, sikap dan tingkat penguasaan siswa program keahlian pemeliharaan kelistrikan sepeda motor kelas XI TSM SMK Negeri 1 Bukittinggi tahun ajaran 2018/2019). Jumlah responden penelitian adalah 36 orang, seperti pada Tabel 1.

Tabel 1. Responden Penelitian

\begin{tabular}{|c|c|c|c|}
\hline Populasi & Jumlah & Informan & Jumlah \\
\hline Siswa kelas XI & & 1. Kepala Sekolah & 1 Orang \\
\hline $\begin{array}{l}\text { yang mengikuti } \\
\text { pembelajaran }\end{array}$ & & $\begin{array}{l}\text { 2. Wakil Kepala Sekolah Bidang Sara } \\
\text { Prasarana }\end{array}$ & 1 Orang \\
\hline pemeliharaan & 28 & 3. Wakil Kepala Sekolah Bidang kurikulu & $1 \mathrm{Or}$ \\
\hline kelistrikan sepeda & Orang & 4. Wakil Kepala Sekolah Bidang h & 1 Orang \\
\hline progam & & 5. Kepala Program Keahlian & 1 Orang \\
\hline keahlian & & 6. Guru Produktif TSM & 1 Orang \\
\hline Sepeda Motor & & 7. Peserta Didik & 2 Orang \\
\hline
\end{tabular}

Informan pada penelitian ini adalah Kepala Sekolah, wakil kepala sekolah bidang:kurikulum, humas, kepala program keahlian teknik otomotif, guru produkti program keahlian pemeliharaan kelistrikan sepeda motor. Populasi pada penelitian ini adalah siswa kelas XI program keahlian Teknik Sepeda Motortahun ajaran 2018/2019. Evaluasi program dalam penelitian ini adalah evaluasi model CIPP yaitu model evaluasi untuk mengetahui tingkat kesesuaian antara standar yang sudah ditentukan dalam program dengan penampilan aktual dari program tersebut. Adapun program yang dimaksud adalah program pembelajaran pemeliharaan kelistrikan sepeda motor di SMK Negeri 1 Bukittinggi tahun ajaran 2018/2019. Berikut akan dijelaskan masing-masing komponen evaluasi: (1)Cotext (konteks) indikatornya :Kebutuhan program, Peluang, Aset, Masalah yang ditemui, (2) Input (masukan) indikatornya :SDM guru,Peserta didik, Sarana prasarana, (3) Process (proses) indikatornya: pelaksanaan 
pembelajaran, aktivitas guru, aktivitas siswa, (4) Product (hasil indikator adalah kemajuan hasil belajar, potensi yang dimiliki, kecakapan, bakat, sikap, dan tingkat penguasaan.

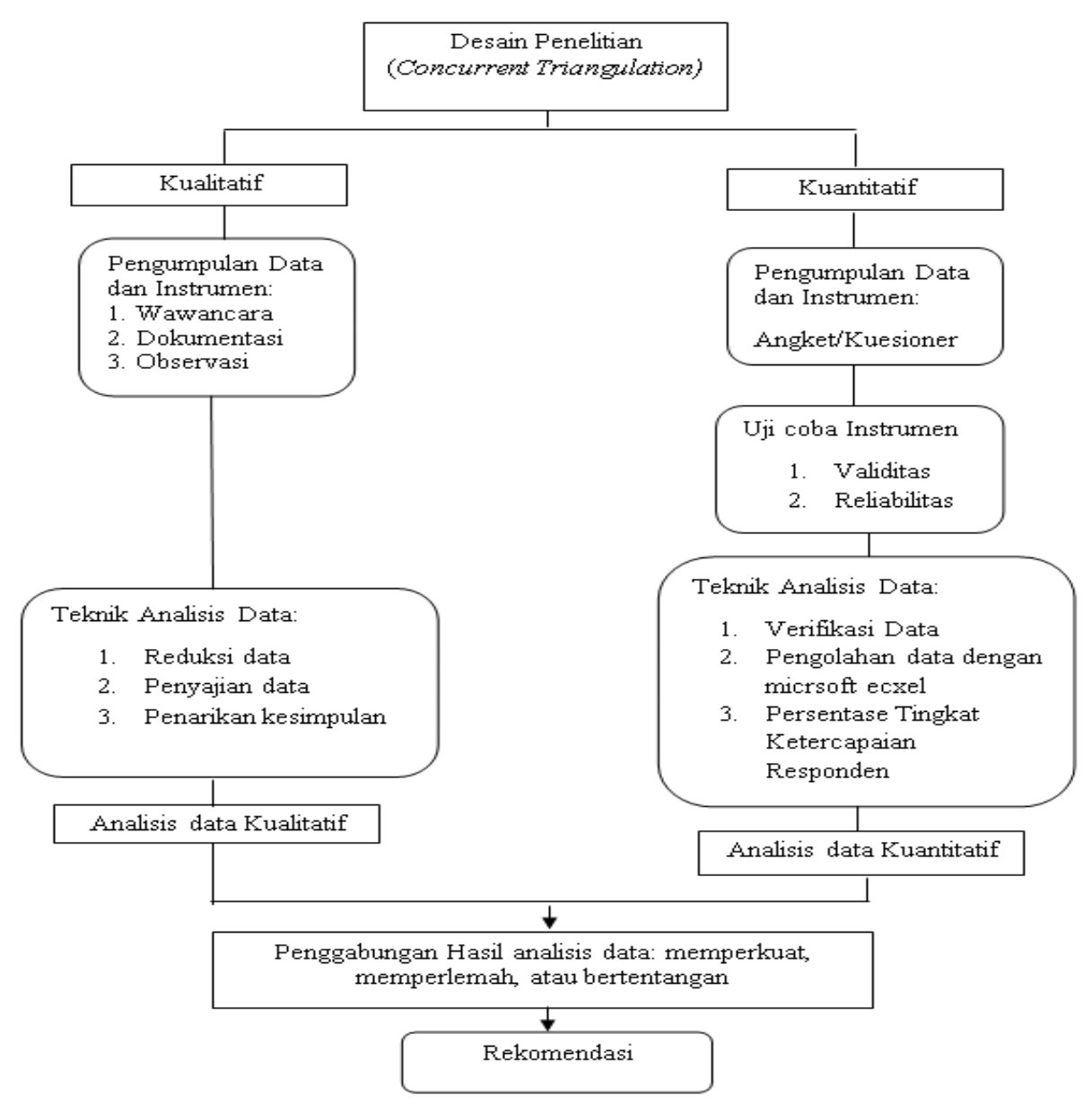

Gambar 1. Diagram Alur Penelitian

Teknik pengumpulan data yang digunakan pada penelitian ini sesuai dengan metode penelitian yang digunakan mixed method, maka teknik pengumpulan data dan instrumen yang digunakan, yaitu secara kuantitatif dan kualitatif. Teknik pengumpulan data kuantitatif yang digunakan dalam penelitian ini adalah dengan kusioner (angket). Pada penelitian ini menggunakan angket tertutup, dimana komunikasi dilakukan dengan cara tidak langsung. Instrumen disusun berdasarkan kajian teori, kemudian dikembangkan menjadi indikatorindikatordan sub indikator dan dilakukan uji validitas berdasarkan rumus product moment.Instrument yang baik disamping harus valid juga harus reliabel. Untuk menguji reliabilitas instrumen digunakan rumus Alpha. Berdasarkan pengujian reliabilitas menggunakan program Microsoft Exeldiketahui nilai koefsiensi untuk keseluruhan indikator reliabilitas instrument sebesar 0, 973 dengan kategori sangat tinggi.

Teknik pengumpulan data dengan menggunakan tiga teknik yaitu wawancara, observasi dan dokumentasi. Adapun indikator yang dinilai adalah kebutuhan, peluang, aset, masalah(Context); SDM Guru, SDM Siswa, Sarana prasarana (Input); Pelaksanaan pembelajaran, Aktivitas guru, Aktivitas siswa (Process); Kemajuan belajar, Potensi yang dimiliki, Kecakapan, bakat, sikap,Tingkat penguasaan (Product). Jenis data yang diambil adalah Data primer yaitu data yang diambil langsung dari informanberupa angket dan data sekunder yaitu data yang diperoleh secara tidak langsung dari sumbernya. Kriteria informan 
yang digunakan dalam penelitian ini adalah (a) informan yang telah cukup lama dan intensif menyatu dalam suatu kegiatan, (b) informan masih terlibat penuh atau aktif pada lingkungan yang menjadi sasaran perhatian penelitian yang dilakukan, dan (c) subjek mempunyai cukup banyak waktu atau kesempatan untuk dimintai informasi.

Tabel. 2. Analisa Validitas Instrumen

\begin{tabular}{llcccc}
\hline Evaluasi & \multicolumn{1}{c}{ Indikator } & $\begin{array}{c}\text { Total } \\
\text { Item }\end{array}$ & $\begin{array}{c}\text { Jumlah } \\
\text { Gugur }\end{array}$ & $\begin{array}{c}\text { No Butir } \\
\text { Gugur }\end{array}$ & $\begin{array}{c}\text { Jumlah } \\
\text { Valid }\end{array}$ \\
\hline \multirow{5}{*}{ Context } & 1. Kebutuhan & 2 & 0 & - & 2 \\
& 2. Peluang & 2 & 0 & - & 2 \\
& 3. Aset & 5 & 1 & 5 & 4 \\
& 4. Masalah & 6 & 0 & - & 6 \\
& 1. Guru & 10 & 3 & $19,22,24$ & 7 \\
\multirow{5}{*}{ Procut } & 2. Peserta didik & 6 & 0 & - & 6 \\
& 3. Sarana Prasarana & 6 & 0 & - & 6 \\
& 1. Pelaksanaan pembelajaran & 3 & 0 & - & 3 \\
& 2. Aktivitas Guru & 7 & 2 & 43,45 & 5 \\
& 3. Aktivitas Siswa & 7 & 2 & 50,54 & 5 \\
& 1. Kemajuan hasil belajar & 2 & 0 & - & 2 \\
& 2. Potensi Yang dimiliki & 3 & 0 & - & 3 \\
& 3. Kecakapan, bakat dan & 7 & 2 & 63,66 & 5 \\
& sikap & 2 & 0 & - & 2 \\
\hline & 4. Tingkat Penguasaan & $\mathbf{6 8}$ & $\mathbf{1 0}$ & - & $\mathbf{5 8}$ \\
\hline
\end{tabular}

Teknik analisa data yang dilakukan adalah dengan metode campuran (Mixed Method) data kuantitatif dan kualitatif. Analisis data kualitatif dalam penelitian ini menggunakan model Miles dan Huberman dapat dilakukan dengan langkah - langkah sebagai berikut: a) Reduksi Data, b) Display Data atau Penyajian Data, c) Mengambil Kesimpulan/Verifikasi (Sugiyono, 2017). Analisis data Kuantitatif dilakukan dengan prosedur dan tahapan sebagai berikut: 1) melakukan pentabulasian data terhadap angket penelitian yang telah diisi oleh responden. 2) melakukan perhitungan setiap indikator. 3) menghitung skor total. 4) menganalisis dengan analisis persentase. Untuk mendiskripsikan data yang telah diperoleh dilakukan dengan tujuan melihat kecendrungan distribusi frekuensi dan menentukan Tingkat pencapaian responden(TPR) pada masing-masing variabel dan indikator menggunakan rumus (Ridwan, 2009).

Tabel 3. Rentang Kategori TPR

\begin{tabular}{cc}
\hline Rentang Persentase & Kategori \\
\hline $90 \%-100 \%$ & Sangat baik \\
$80 \%-89 \%$ & Baik \\
$65 \%-79 \%$ & Cukup \\
$55 \%-64 \%$ & Kurang \\
$0 \%-54 \%$ & Kurang Sekali \\
\hline
\end{tabular}




\section{Hasil dan Pembahasan Komponen Context}

Indikator kebutuhan terhadap program mendapatkan nilai rata-rata $91,07 \%$ yang mana indikator tersebut berada pada kategori sangat baik, data kualitatif pada indikator kebutuhan juga mendukung penelitian ini, yang mana kebutuhan pada program pembelajaran pemeliharaan kelistrikan sepeda motor ini sudah terpenuhi, seperti guru yang berkompeten, siswa, mekanik yang handal, kurikulum dan fasilitas bengkel. Jadi indikator ini sudah mendukung untuk melaksanakan program pembelajaran pemeliharaan kelistrikan sepeda motor.

Indikator peluang yang dimiliki mendapatkan nilai rata-rata $82,86 \%$ yang mana indikator tersebut termasuk pada kategori baik, peluang disini adalah peluang yang diberikan oleh sekolah dan peluang yang diberikan oleh pihak industri, data kualitatif pada indikator peluang mendukung penelitian ini, yang mana sekolah memberikan peluang bagi siswanya untuk memilih sendiri tempat praktek kerja industri yang mereka inginkan, ini bertujuan agar siswa lebih bertanggung jawab atas pilihannya sendiri, dan lebih termotivasi untuk praktek. Sedangkan peluang yang diberikan pihak stekholder adalah kesempatan bekerja di bengkel resmi sepeda motor, pihak stekholder akan merekrut siswa yang mempunyai kompetensi sesuai kulifikasi dari pihak stekholder. jadi pada indikator ini mendukung terlaksananya program pembelajaran pemeliharaan kelistrikan sepeda motor.

Indikator aset yang dimiliki mendapatkan nilai rata-rata 79,29\% yang mana pada indikator ini termasuk pada kategori cukup, hal yang perlu diperbaiki disini yaitu: 1) pelayanan toolman, toolman disini bertanggung jawab dalam proses pembelajaran praktek, toolman bertugas menyiapkan alat dan bahan praktek. 2) kurangnya kegiatan disekolah yang dapat meningkatkan kompetensi kejuruan siswa, kegiatan ini contohnya seminar tentang teknologi terbaru sepeda motor atau servis gratis yang dilakukan oleh siswa teknik sepeda motor, kegiatan ini sangat bermanfaat bagi siswa karena dapat menambah pengalaman dan pengetahuan siswa tentang sepeda motor. Data kualitatif mendukung temuan ini, yang mana kegiatan yang dilakukan sekolah cukup minim, sekolah kurang aktif dalam melakukan kegiatan- kegiatan untuk menunjang kompetensi siswanya. Jadi pada indikator ini sudah cukup mendukung terlaksananya pembelajaran pemeliharaan kelistrikan sepeda motor, tetapi masih perlu adanya perbaikan seperti mengadakan kegiatan-kegiatan untuk menunjang kreativitas dan kompetensi siswa.

Indikator masalah yang ditemui mendapatkan nilai rata-rata $77,98 \%$ berada pada kategori cukup. Adapun hal yang perlu pada indikator ini adalah: 1) Lingkungan sekolah, lingkungan belajar disekolah kurang kondusif untuk melakukan proses pembelajaran, banyak siswa yang tidak ikut praktek karena kekurangan fasilitas praktek seperti kunci-kunci dan ruangan praktek, akibatnya siswa banyak yang bermalasan saat belajar dan sering tidak masuk saat jam pelajaran, temuan data kualitatif juga mendukung pada indikator ini, banyak siswa yang kurang disiplin karena masalah fasilitas belajar, jadi hal ini harus diperhatikan agar siswa lebih efektif saat proses pembelajaran. 2) Lingkungan praktikum, banyak siswa yang belum mempunyai kompetensi saat selesai praktikum. Temuan data kualitatif mendukung pada pada indikator ini, ada beberapa pembimbing praktikum yang kurang membagikan ilmunya ke siswa, mereka merasa terganggu karena kehadiran siswa praktikum, jadi harus diperhatikan lagi jumlah siswa saat praktikum.

\section{Komponen Input}

Indikator SDM guru mendapatkan nilai rata-rata 84,39\% yang mana indikator tersebut berada pada kategori baik, Guru produktif teknik sepeda motor sebagian sudah sesuai dengan kualifikasi pendidikannya, pelatihan untuk meningkatkan kompetensi guru sudah terlaksana dengan sangat baik, jumlah guru produktif TSM masih kurang,sedangkan untuk kompetensi 
guru (pedagogik, profesional, sosial dan kepribadian) pada data kuantitatif sudah termasuk kategori baik

Indikator TPR siswa mendapatkan nilai rata-rata $86,31 \%$ yang mana indikator tersebut berada pada kategori baik. Minat siswa dalam melaksanakan pembelajaran pemeliharaan kelistrikan sepeda motor menurut tergolong baik, motivasi siswa dalam menjalankan program ini cukup tinggi. Indikator sarana dan prasarana mendapatkan nilai rata-rata 74,40\% yang mana nilai ini termasuk pada kategori cukup, ada beberapa aspek yang masih perlu diperbaiki yaitu: Peralatan praktek yang belum lengkap, bahan praktek yang kurang lengkap dan ruangan praktek yang kurang memadai.

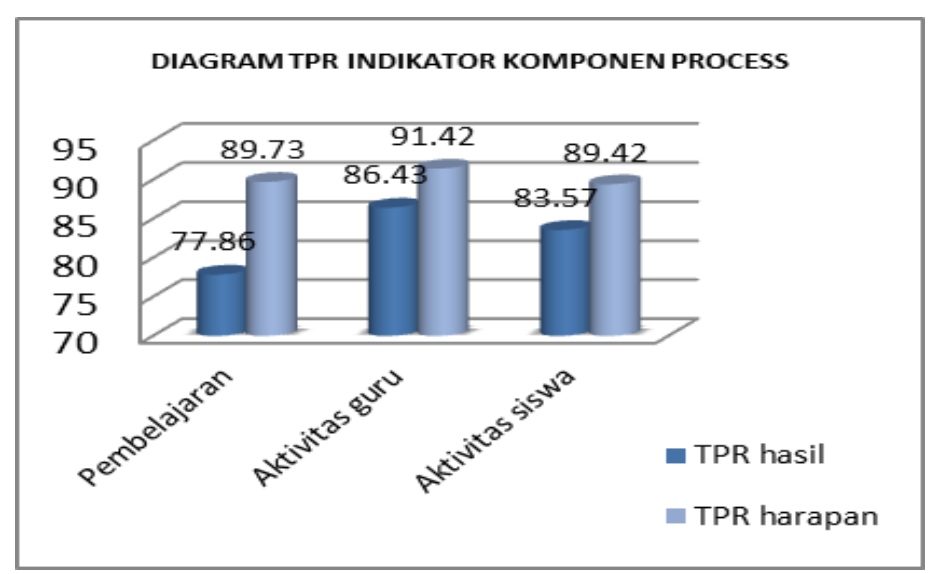

Gambar 2. Diagram TPR Komponen Process

\section{Komponen Product}

Peningkatan hasil belajarmendapatkan nilai rata-rata 73,57\% yang mana termasuk pada kategori cukup, data kuantitaif ini didukung oleh data kualitatif, menurut informan tidak semua siswa yang mengalami peningkatan hasil belajar, hanya siswa yang benar-benar mau belajar saja yang nilainya meningkat, siswa yang malas belajar selama ini tindak mengalami peningkatan, dan melakukan remedial untuk memperbaiki nilainya. Potensi yang dimiliki mendapatkan nilai rata-rata $78,33 \%$ yang termasuk pada kategori cukup. Data kualitatif mendukung penelitian ini, potensi yang dimiliki siswa dalam menjalankan program ini secara umum belum tergolong baik, karena siswa kurang mendapatkan pembelajaran yang maksimal di sekolah dan kurang mendapatkan pengalaman di industri, sehingga kemampuan beberapa siswa belum bisa dimanfaatkan oleh lingkungan sekitar.

Kecakapan, bakat dan sikap mendapatkan nilai rata-rata $78,57 \%$ berapada pada kategori cukup. Temuan data kualitatif mendukung penelitian ini, karena beberapa dari siswa belum mempunyai keterampilan yang dibutuhkan oleh indutri, dan beberapa siswa belum bisa menyelesaikan pekerjaan sendiri tanpa bantuan mekanik, bakat siswa juga belum terlihat saat melakukan praktikum, siswa yang berbakat akan mudah menyesuaikan diri dengan pekerjaannya, dan sikap siswa di perusahaan sudah cukup baik, siswa mampu menyesuaikan diri dengan mekanik yang ada dibengkel.

Tingkat penguasaan mendapatkan hasil rata-rata 74,64\% yang mana juga berada pada kategori cukup. Data kualitatif mendukung penelitian ini, infoman menyebutkan sebagian siswa belum mampu menerapkan ilmu yang didapat di sekolah dan beberapa siswa belum bisa bekerja sesuai dengan standar operational prosedur, hal ini sudah jelas berarti tingkat penguasaan siswa terhadap pelajaran masih rendah.

Dari hasil penelitian yang dilakukan di SMK Negeri 1 Bukittinggi tentang pelaksanaan pembelajaran pemeliharaan kelistrikan sepeda motor program di SMK Negeri 1 
Bukittinggi dilihat dari contexs, input, prosess dan product. Secara keseluruhan rata-rata hasil evaluasi pembelajaran pemeliharaan kelistrikan sepeda motor adalah sebesar $81,00 \%$ artinya berada pada kategori baik. Walaupun secara keseluruhan berada pada kategori baik, namun masih ada beberapa indikator yang perlu dilakukan perbaikan.

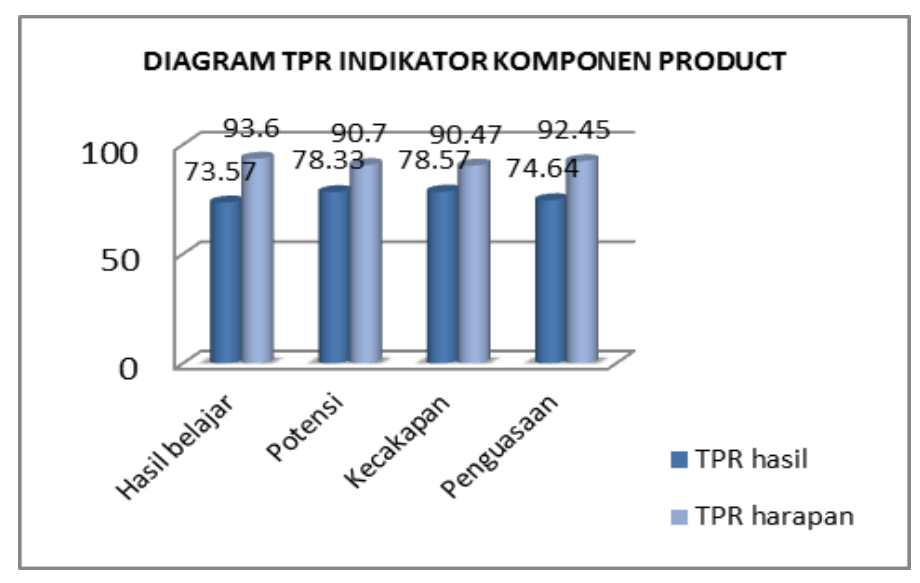

Gambar 3. Diagram TPR Komponen Product.

Berdasarkan analisa data secara keseluruhan konteks dalam pelaksanaan pembelajaran pemeliharaan kelistrikan sepeda motor berada pada kategori baik, tetapi ada beberapa indikator yang masih perlu diperbaiki lagi, seperti indikator aset dan masalah, indikator ini harus ditingkatkan lagi efektifitasnya agar hasil belajar siswa juga meningkat.

Berdasarkan analisa data disimpulkan bahwa komponen input dalam pelaksanaan pembelajaran pemeliharaan kelistrikan sepeda motor masih terdapat kekurangan pada bagian tertentu. Dilihat pada aspek guru masih perlu ada penambahan guru lagi, karena guru yang sekarang sudah terlalu banyak jam mengajar dan tugas sekolah yang lain, sehingga guru tersebut kurang optimal dalam mengajar. Guru memiliki peran yang penting selain sebagai perencana dan pelaksana program pembelajaran, mempunyai kewajiban menilai (Widoyoko, 2013). Dari aspek alat dan bahan praktek juga masih perlu diperhatikan lagi, masih banyak kunci-kunci yang kurang dan sepeda motor untuk praktek perlu ditambah lagi, dan dari segi ruangan praktek juga masih belum memadai, kapasitas ruang praktek sekarang tidak bisa menampung jumlah siswa yang banyak, jadi harus ada penambahan ruangan praktek lagi agar pembelajaran lebih optimal.

Pada proses dalam pelaksanaan pembelajaran pemeliharaan kelistrikan sepeda motor sudah termasuk pada kategori baik, baik disini berarti bahwa dalam komponen proses pelaksanaan pembelajaran pemeliharaan kelistrikan sepeda motor ini sudah mendukung dalam melaksanakan program kerjasama ini dan sudah sesuai dengan yang diharapkan oleh pihak sekolah dan pihak industri, tetapi ada beberapa indikator yang masih perlu diperbaiki lagi, seperti aktivitas guru dan aktivitas siswa, agar proses pembelajaran lebih maksimal.

Pada komponen product dalam penelitian ini dapat disimpulkan bahwa product dalam pelaksanaan pembelajaran pemeliharaan kelistrikan sepeda motor sudah tergolong cukup, dengan demikian dapat dikatakan bahwa komponen evaluasi produk sudah memenuhi harapan untuk pelaksanaan pembelajaran pemeliharaan kelistrikan sepeda motor dengan terlebih dahulu memperbaiki beberapa aspek yang bermasalah, Yang mana pada komponen ini semua indikator berada pada kategori cukup, berarti semua indikator pada komponen ini harus diperbaik lagi untuk mendapatkan hasil yang lebih baik.

Evaluasi produk merupakan penilaian yang dilakukan untuk mengukur keberhasilan dalam mencapai tujuan yang telah ditetapkan. Kriteria yang digunakan dalam melanjutkan 
suatu program dalam melakukan evaluasi adalah apabila hasil evaluasi mempunyai kecendrungan minimal cukup maka program dapat dilanjutkan dengan melakukan beberapa perbaikan pada komponen yang telah dievaluasi. Hasil penelitian yang secara kuantitatif dan kualitatif mengungkapkan bahwa produk program pembelajaran pemeliharaan kelistrikan sepeda motor berada pada kategori cukup. Cukup di sini bermakna bahwa dari segi hasil belajar telah memenuhi persyaratan ketuntasan dalam belajar, tingkat penguasaan, potensi, bakat, dan sikap yang dimiliki oleh siswa merupakan suatu bekal bagi mereka nantinya dalam mencari pekerjaan, sehingga ketercapaian dalam pelaksanaan pembelajaran pemeliharaan kelistrikan sepeda motor selama belajar dapat disimpulkan cukup baik.

Beberapa penelitian sebelumnya menunjukkan bahwa evaluasi program pembelajaran dengan model CIPP dinyatakan cukup efektif (Budi Yoga Bhakti, 2017). Temuan penelitian mengenai evaluasi program pendidikan pemakai dengan model CIPP di perpustakaan Fakultas Teknik UGM menghasilkan evaluasi setiap komponen program pendidikan cukup baik (Wijayanti et al., 2019). Temuan lain menyatakan evaluasi pemanfaatan program information communication technology (ICT) menggunakan model CIPP pada sekolah menengah di Kota Padang memperoleh evaluasi yang jelas menggunakan model CIPP (Hidayati, 2010). Selain itu, model CIPP digunakan untuk mengevaluasi pembelajaran di PAUD inklusif menghasilkan evaluasi setiap komponen cukup baik (Junanto \& Kusna, 2018). Beberapa temuan tersebut menunjukkan model CIPP ini baik digunakan untuk mengevaluasi program pembelajaran. sehingga dalam penelitian ini memilih model CIPP dalam evaluasi program pembelajaran pemeliharaan kelistrikan sepeda motor di SMK Negeri 1 Bukittinggi

\section{Simpulan}

Mengacu pada rumusan masalah serta berdasarkan analisis dan pembahasan dapat ditarik kesimpulan bahwa pelaksanaan pembelajaran pemeliharaan kelistrikan sepeda motor di SMK Negeri 1 Bukittinggi sudah berada pada kategori baik, dan tiap komponen evaluasinya sudah mendukung terlaksananya program pembelajaran pemeliharaan kelistrikan sepeda motor, tetapi untuk mendapatkan hasil yang optimal masih perlu ada perbaikan lagi pada bagian indikator yang termasuk dalam kategori kurang atau cukup, seperti indikator: Aset yang dimiliki, masalah lingkungan, SDM guru, sarana prasarana, pelaksanaan pembelajaran, aktivitas guru, peningkatan hasil belajar, potensi yang dimiliki, kecakapan dan tingkat penguasaan. oleh karena itu, untuk mendapatkan hasil yang lebih baik lagi, kepada pihak sekolah dan pihak stekholder agar lebih memperhatikan dan memperbaiki aspek tersebut. Berdasarkan hasil temuan penelitian evaluasi program pembelajaran kelistrikan sepeda motor untuk memperoleh hasil yang lebih baik maka disarankan Workshop/bengkel di sekolah harusnya memiliki seorang toolman, toolman bertanggung jawab atas peralatan praktek yang digunakan siswa, Guru produktif Teknik Sepeda Motor Honda harusnya ditambah, karena belum sebanding dengan jumlah siswa Teknik Sepeda Motor, Sarana dan prasarana dilengkapi mendukung hasil belajar siswa, dan keterampilan peserta didik ditingkatkan.

\section{Daftar Rujukan}

Arifin, M. Z., Ulfa, S., \& Praherdhiono, H. (2018). Pengembangan kurikulum muatan lokal karawitan sebagai upaya mengkonstruksi pengetahuan dan pelestarian budaya jawa di jenjang sma. Jurnal Kajian Teknologi Pendidikan, 1(2), 2-10. http://journal2.um.ac.id/index.php/jktp/article/view/3707.

Arifin, Z., Indonesia, U. P., \& Kejuruan, S. M. (2012). Implementasi Manajemen Stratejik Berbasis Kemitraan Dalam Meningkatkan Mutu SMK (Studi Pada SMK Kelompok Teknologi Bidang Otomotif di Kota Yogyakarta). Jurnal Administrasi Pendidikan 
UPI, 14(1), 60-70. https://doi.org/10.17509/jap.v14i1.6708.

Budi Yoga Bhakti. (2017). Evaluasi Program Model CIPP Pada Proses. Jurnal Inovasi Pendidikan Fisika Dan Riset Ilmiah, 1(2), 75-82. http://www.journal.stkipnurulhuda.ac.id/index.php/JIPFRI/article/view/109/71.

Djuandi. (2013). Permendikbud tentang Kurikulum Tahun 2013.

Fajri, K. N. (2019). Proses Pengembangan Kurikulum. Jurnal Keislaman Dan Ilmu Pendidikan, 1(2), 35-48. https://ejournal.stitpn.ac.id/index.php/islamika.

Hidayati, A. (2010). Evaluasi Pemanfaatan Program Information Communication Technology (ICT) Menggunakan Model CIPP Pada Sekolah Menengah Di Kota Padang. Ilmiah Ilmu Pendidikan, 10(2), 40-46. http://ejournal.unp.ac.id/index.php/pedagogi/article/view/2244.

Junanto, S., \& Kusna, N. A. A. (2018). Evaluasi Program Pembelajaran di PAUD Inklusi dengan Model Context, Input, Process, and Product (CIPP). Inklusi, 5(2), 179. https://doi.org/10.14421/ijds.050202.

Muhammedi. (2016). Perubahan kurikulum di indonesia: studi kritis tentang upaya menemukan kurikulum pendidikan islam yang ideal. Raudhah, 4(1), 49-70. https://doi.org/10.30829/raudhah.v4i1.61.

Munthe, A. P. (2015). Pentingnya Evaluasi Program Di Institusi Pendidikan: Sebuah Pengantar, Pengertian, Tujuan dan Manfaat. Scholaria: Jurnal Pendidikan Dan Kebudayaan, 5(2), 1. https://doi.org/10.24246/j.scholaria.2015.v5.i2.p1-14.

Ridwan. (2009). Dasar-dasar Statistika. Alfabeta.

Sakti, U. (2018). Arabic Language Learning Evaluation in Higher Education with Context Input Process Product (CIPP) Model. Alsinatuna, 4(1), 33. https://doi.org/10.28918/alsinatuna.v4i1.1591.

Slameto, S. (2015). Rasional Dan Elemen Perubahan Kurikulum 2013. Scholaria: Jurnal $\begin{array}{llll}\text { Pendidikan Dan } & \text { Kebudayaan, } & 5(1), & 1 .\end{array}$ https://doi.org/10.24246/j.scholaria.2015.v5.i1.p1-9.

Sugiyono. (2017). Metode Penelitian Kuantitatif, Kualitatif, dan R\&D. Alfabeta.

Widoyoko, S. E. P. (2013). Optimalisasi Peran Guru dalam Evaluasi Program Pembelajaran. Jurnal Pendidikan, 22(2), 1-12. http://ejurnal.veteranbantara.ac.id/index.php/pendidikan/article/view/148.

Wijayanti, N. I., Yulianti, R., \& Wijaya, B. (2019). Evaluasi Program Pendidikan Pemakai Dengan Model CIPP di Perpustakaan Fakultas Teknik UGM. Tik Ilmeu : Jurnal Ilmu Perpustakaan Dan Informasi, 3(1), 37. https://doi.org/10.29240/tik.v3i1.790. 